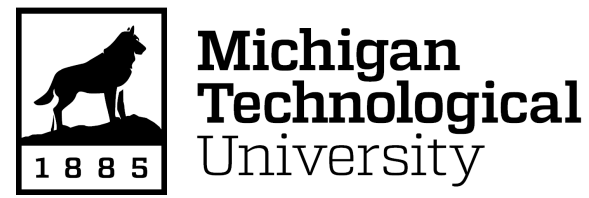

Michigan Technological University Digital Commons @ Michigan Tech

Dissertations, Master's Theses and Master's Reports

2019

\title{
A STUDY ON THE CHALLENGES TO BOYS' EDUCATION IN SABIE, MOZAMBIQUE
}

Rachel Ledebuhr

Michigan Technological University, rjledebu@mtu.edu

Copyright 2019 Rachel Ledebuhr

\section{Recommended Citation}

Ledebuhr, Rachel, "A STUDY ON THE CHALLENGES TO BOYS' EDUCATION IN SABIE, MOZAMBIQUE", Open Access Master's Report, Michigan Technological University, 2019.

https://doi.org/10.37099/mtu.dc.etdr/810

Follow this and additional works at: https://digitalcommons.mtu.edu/etdr

Part of the Bilingual, Multilingual, and Multicultural Education Commons 


\title{
A STUDY ON THE CHALLENGES TO BOYS' EDUCATION IN SABIE, MOZAMBIQUE
}

\author{
By \\ Rachel J. Ledebuhr
}

\begin{abstract}
A REPORT
Submitted in partial fulfillment of the requirements for the degree of MASTER OF SCIENCE

In Applied Science Education
\end{abstract}

MICHIGAN TECHNOLOGICAL UNIVERSITY

2019

(C) 2019 Rachel J. Ledebuhr 
This report has been approved in partial fulfillment of the requirements for the Degree of MASTER OF SCIENCE in Applied Science Education.

Department of Cognitive and Learning Sciences

$\begin{aligned} \text { Report Advisor: } & \text { Shari Stockero } \\ \text { Committee Member: } & \text { Kari Henquinet } \\ \text { Committee Member: } & \text { Amy Lark } \\ \text { Department Chair: } & \text { Susan Amato-Henderson }\end{aligned}$




\section{Table of Contents}

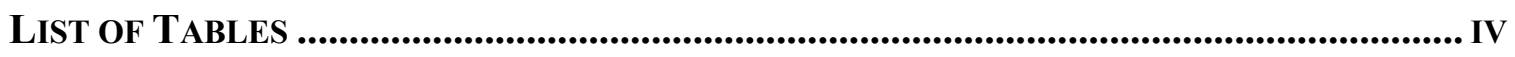

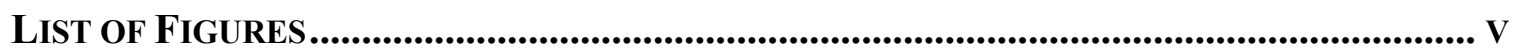

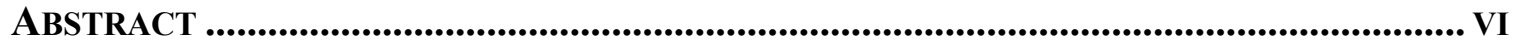

CHAPTER 1: INTRODUCTION ...........................................................................................1

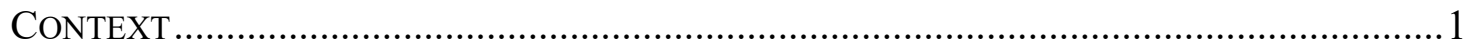

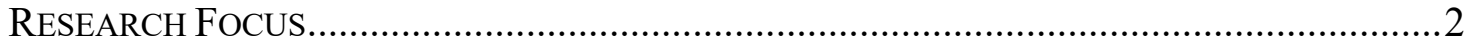

CHAPTER 2: LITERATURE REVIEW .....................................................................4

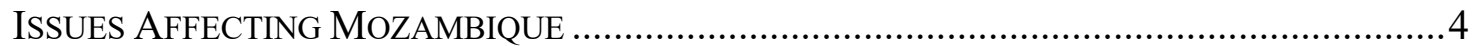

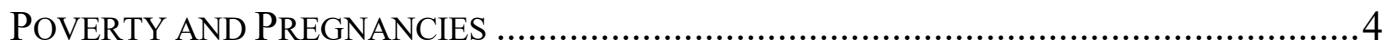

SABIE GAME PARK AND RHINO POACHING .................................................... 5

SOUTH AFRICA WORK LURES....................................................................... 9

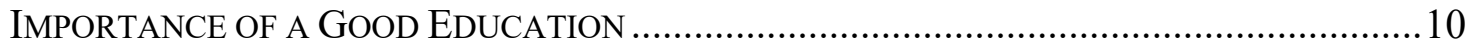

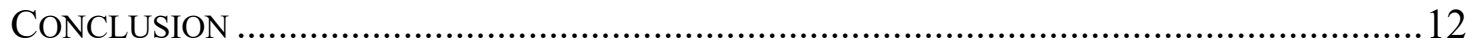

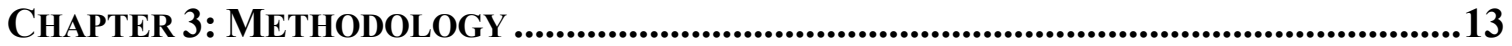

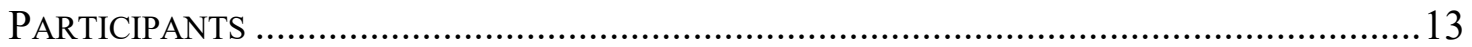

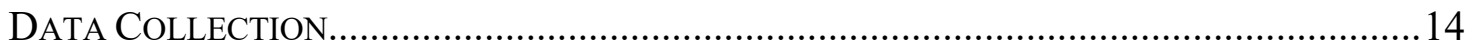

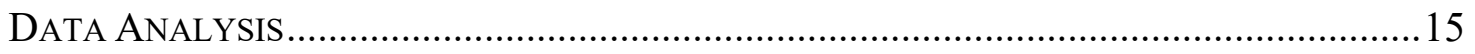

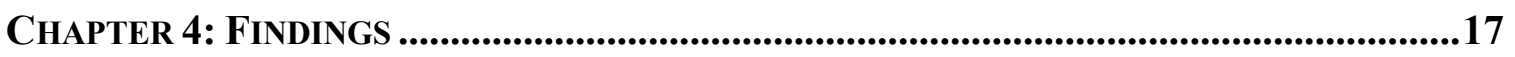

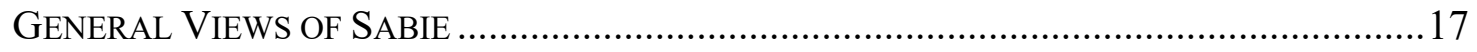

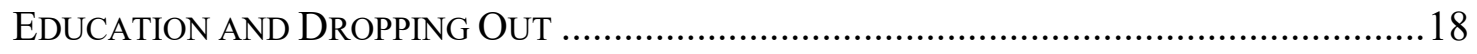

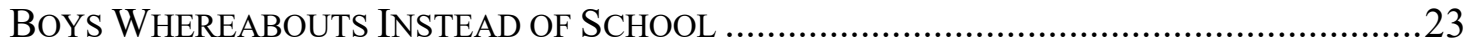

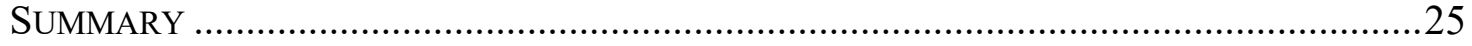

ChAPTER 5: DISCUSSION AND CONCLUSION ...............................................................26

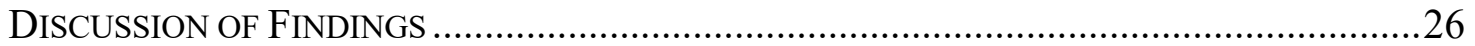

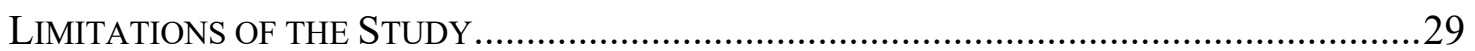

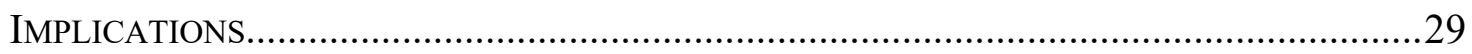

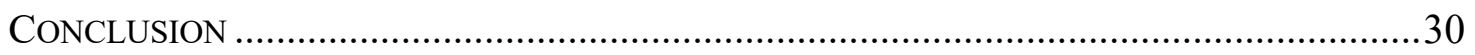

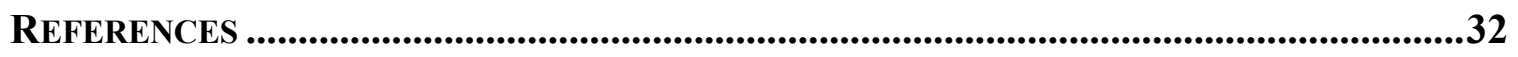




\section{List of Tables}

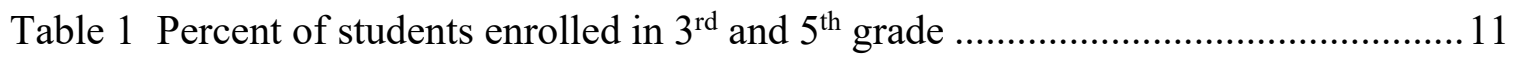

Table 2 Reasons boys are dropping out ........................................................... 19

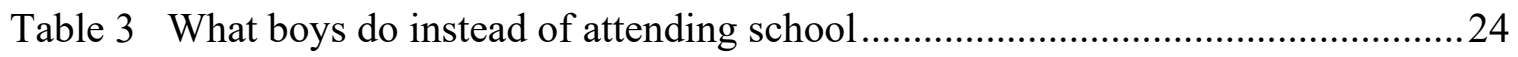




\section{List of Figures}

Figure 1 The main questions asked in the interviews................................................ 15

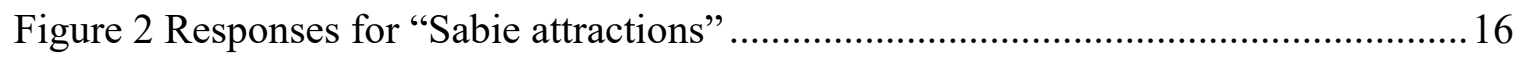




\begin{abstract}
Much research has been conducted on struggles related to female retention rates in schools in Africa. Yet, it was observed that boys are not completing their education, as well, in the region of Sabie, Mozambique. Utilizing semi-structured interviews, this study focused on the challenges that boys face in Sabie that cause them to stop their education, as well as investigated where they go instead of attending school. This qualitative study with six non-student participants from the community, six current students and five drop outs, indicated that boys mainly drop out due to financial problems. Results also indicated that when they quit school they find a variety of ways to make money, including poaching rhino horn, working in South Africa and working for local businesses and farms. It is important that boys stay in school, since it has been shown that education helps advance the economy of any country (Solberg, 2015). The results suggest that by improving conditions in the area, and creating more job opportunities that respect a good education, boys might stay in school longer and uplift not only the village, but also the whole country.
\end{abstract}




\section{Chapter 1: Introduction}

At the conclusion of the 2017 school year, it was found that more than 465,000 students had dropped out of primary school in Mozambique. Primary school in Mozambique is free and compulsory for the first 7 years. A child may enter $1^{\text {st }}$ grade at the age of 6 years old, and after passing $7^{\text {th }}$ grade may choose to continue with secondary school, enter a primary teacher training institution or attend basic technical and vocational schools (SACMEQ, 2019). Although the 2017 drop-out number is less than the previous year, it is still alarming. Contrary to common research that indicates a high dropout rate among female students, of those students, 252,051 were males and the remaining 212,995 were females, showing that more boys actually dropped out than girls during that school year (Club of Mozambique, 2018). The purpose of this study is to investigate why the boys are dropping out, from the perspectives of current students, drop outs and community members, and where the boys go or what they do instead of completing their education.

\section{Context}

I am a Returned Peace Corps Volunteer and worked as an $8^{\text {th }}$ grade math teacher, living in Sabie village, in the district of Moamba, in the southernmost province of Mozambique, Maputo. The village sits about $100 \mathrm{~km}$ from the capital, Maputo City. The people of Sabie are machangana, meaning they are part of the Shangaan tribe. The Shangaan are part of the Tsonga tribes that lived in Mozambique in the mid 1800s. King Shaka of the Zulus of South Africa sent Soshangana to conquer the Tsonga people in what is now southern Mozambique. When Soshangana arrived, he found peaceful people 
and fertile land and decided to stay. He taught them the Zulu way of fighting, but did not alter their ways of constructing round huts or cooking. He gave his name to the people, becoming the Shangaan tribe. But Shaka sent troops to attack the Shangaan tribe, only to be defeated, and the tribe again had to fight the Portuguese in 1833 and 1834.

Soshangana died in 1858 , which led to a six-year war between his two sons fighting over power, and Muzila won in the Sabie river in 1862 (Shangana Cultural Village, 2019). During this time, the Portuguese colonists became more involved in trade and Shangaan men went to work on the gold minds in Johannesburg. Through different tribe leaders, the Shangaans helped fight the Portuguese to gain Mozambican independence in 1975 under the rule of Mozambique Liberation Front (Frelimo). However, the country then experienced a civil war from 1977-1992 between Frelimo and an anti-Communist organization (Renamo). Some Shangaan people fled the country, moving into South Africa, but many stayed and fought. The Shangaan people of Sabie also endured severe flooding in 2000 and 2001. Due to wars, flooding and droughts, Mozambique is still a poor country but is considered a fast growing economy (Lambert, 2018).

\section{Research Focus}

I taught three classes at the secondary school, each with about 65 students in them. In one of my classes during my first year of teaching, I started with 35 male students, ranging from age 14-25 and ended the year with just 23 boys. By the second trimester during my second year of teaching, 11 students had dropped out, including 8 male students. My observations contradicted the general information about education in Mozambique, and Africa as a whole, that have reported girls with a higher dropout rate (Chazen, 2017; Salvi, 2018). Hence, my research questions were: 
a. What are the challenges and pressures that boys in Sabie face that pull them away from education?

b. Where are the boys of Sabie going instead of heading to school?

This study aims to understand some of the challenges that these boys face that complicate their completion of education, specifically in the area of Sabie, Mozambique. This project is part of my requirements as a graduate student in the Peace Corps Masters International program, which requires me to conduct original research while simultaneously and separately fulfilling my duties as a Peace Corps Volunteer. While serving as a Peace Corps Volunteer, I identified this issue and sought to research it further. 


\section{Chapter 2: Literature Review}

Many theories have been proposed on what motivates students to drop out of school in Mozambique, and in Africa in general. Although the literature covers a number of reasons, this chapter will focus on the main issues that emerge repeatedly throughout the literature reviewed. These reasons are: poverty, pregnancies, rhino poaching, and work opportunities in South Africa. Although the literature explains these challenges in a variety of contexts, this chapter will focus on their impact on boys' education in Sabie, Mozambique, as well as the importance of education, in general, to Mozambique.

\section{Issues Affecting Mozambique}

\section{Poverty and Pregnancies}

Although Mozambique has worked to improve its poverty status, about 80 percent of Mozambicans still live on less than two dollars per day and thus live in poverty. Mozambique ranks 181 out of 187 countries in the most recent United Nations Development Programme's Human Development Index (Blessman, 2017). This index takes into account life expectancy, access to education and Gross National Income (GNI) to make its rankings. The current life expectancy in Mozambique is 57.6 years, while in the United States it is 79 years old. Malaria and HIV are prevalent amongst Mozambicans and, in fact, Mozambique has the eighth highest prevalence of HIV in the world. Further, malaria accounts for 42 percent of child deaths under the age of 5-years old. On top of malaria and HIV, almost one-third of the population of Mozambicans suffers from malnutrition and over half of Mozambicans do not have access to clean water (Blessman, 2017). 
According to the UN children's agency Unicef, around half (48 percent) of Mozambican women marry before they turn 18 (Salvi, 2018). Furthermore, 46 percent of girls between the ages of 15 and 19 are either currently pregnant or already mothers. This, in turn, impoverishes the community as the young girls cannot support the child. Mozambican education policy dictates that both parties of a pregnant pair may not attend class during the day to not encourage pregnancies, but instead only may attend if the school offers night classes, though few do. However, many boys try to lie or hide the fact that they are the unborn baby's father. The young women look to the baby's fathers for money, and many do not have it. If the father is an adolescent in school, chances are he will leave school, if he has not already, to try and provide for his new child. The villagers of Sabie are no exception and many live with these factors daily (Salvi, 2018).

\section{Sabie Game Park and Rhino Poaching}

As the crow flies, the village of Sabie is only $25 \mathrm{~km}$ from the border of South Africa. This border is not just any part of South Africa. It is Kruger National Park, one of the largest game reserves in Africa. Next to Kruger on the Mozambique side is the wildlife conservancy called Sabie Game Park (SGP). SGP is a private hunting game park that covers 30,000-hectares (about 74,000 acres), and is part of the Great Limbobo TransFrontier Conservancy Area (GLTCA). SGP is owned by white South Africans but employs many locals, as well as Zimbabweans, to help run the whole park and conservancy, which was created in the year 2000. During the war from 1977 - 1992 many locals fled to hide out in the mountains and in the Mozambican bush. When the civil war ended, many locals had settled into the area that is now SGP. SGP helped build houses to resettle locals, but now the fenced off area closes off a few water sources and gravesites 
that had become important for locals. SGP still allows locals to occasionally visit the gravesites, under supervision, but many locals still view that SGP took from them what they can't get back. This situation has created a rift between the locals and SGP, and many locals have a sour view of SGP and its workers, making it difficult for the two communities to work together in a harmonious way.

SGP hosts all sorts of African animals, such as zebra, hippopotamus, elephants, cape buffalo, leopard, and lion. But the most important to note, is that SGP is the only park in all of Mozambique that still has a residency of rhinos. All other parks and reserves in Mozambique that once had rhinos have all been wiped out by poaching. This has dramatically affected Sabie and the surrounding villages as they are communities directly connected to SGP via poaching and poachers (Clough, 2014; Masse, Gardiner, Lubilo, \& Themba, 2018; Totland, 2016). Because the population of rhinos is nearby, Sabie is a town full of rhino poachers. Locals will enter into the park and test their luck at trying to poach a rhino for its horn or assist others in the process of doing so. The rhino horn is worth a lot of money, driven by the market in Asia, specifically Vietnam. While the allure stems from Asia, $80 \%$ of the world's rhinos live in South Africa, specifically in Kruger National Park (Totland, 2016). The horn is sought after mainly because of the belief that the horn ground up to a powder cures a wide variety of ailments, such as hangovers and cancer, and is also used as an aphrodisiac. Yet the material the horn is made of, keratin, is the same protein found in human fingernails and hair, and has zero medical properties. The rhino horn is currently worth more than gold or cocaine, per kilogram. Each horn varies between $1-3 \mathrm{~kg}$ and may go for $\$ 65,000-80,000$ per kilogram (Hsu, 2017). In Mozambique, professions including police officers, guards and teachers, 
may earn 3,000 meticais (the local currency) per month, or \$50 USD with the current exchange rate. That means that in a year, a Mozambican with a job could earn $\$ 600$. Therefore, just one rhino horn could earn the same as a working Mozambican over 100 years. Furthermore, the majority of locals are unemployed and provide for their families by tending to their farm and selling their bounty, livestock, or charcoal or re-selling goods bought in South Africa. Locals that live in some of the highest poverty levels see the "easy wealth" nearby in the form of a rhino horn, and illegally enter the park (Fenio, 2014).

Sabie has had several successful poachers, and it is not a town secret who they are. They may build themselves nice houses complete with air conditioning and own several cars, motorcycles and big screen TVs or pools, but others may also give back to the community by building and running stores, bars, chapas (the local transportation). They also send their own kids to school. The village of Sabie, therefore, would not be what it is today without poachers. But at the same time, lives are lost because of poaching, other poachers drink their winnings away, and young boys aspire or are demanded to be poachers. In a rally held in April of 2018 in Sabie, Mozambican President Filipe Nyusi urged the population to denounce all those who are directly or indirectly involved in poaching. Nyusi explained, "We are losing sons and brothers because they are practicing an activity which only enriches other people," analyzing that poaching profits organized crime networks and not the poachers, themselves. The president concluded saying, "It's better to earn a little out of decent work than wanting to be rich all at once while your life is in constant risk" (Agencia de Informacao de Mocambique, 2018). 
SGP keeps its animals protected by the International Anti Poaching Foundation (IAPF) or more informally known as the Anti Poaching Unit (APU), a non-governmental organization (NGO). The APU primarily employs green military tactics, and is comprised of young ex-military men from various countries. They are responsible for patrolling the perimeter every day by foot, car and plane or helicopter. The relationship between the community of Sabie and the APU is a tense one, stemming from the idea that their motives may not always agree with one another. However, SGP also employs scouts from the local community that could perhaps one day work themselves up to becoming a guide or a ranger. They are provided with a salary just above minimum wage, and patrol the outside of the SGP's fencing, as well as provide knowledge about the community and local life (Masse et al., 2017).

Rhino poaching system has been explained by using a 5-tier method to classify those involved, as designed by the Focus Africa Foundation (Masse et al., 2017). It is as follows:

Level 1: The poachers that illegally enter the park, armed with guns, machetes, materials from the currendeiro (witch doctor) to help them along their journey, and food and water supplies. They are mostly local young men.

Level 2: The crime bosses. These men are the first to receive the rhino horn, and control the Level 1 poachers, financing them and providing guns. Typically, these men are the ones to show off their wealth in the community. 
Level 3: The second receivers of the rhino horn, generally Vietnamese or Chinese nationals living in South Africa or Mozambique. They purchase the horn from Level 2 men and transport their bounty to Asia.

Level 4: Asian receivers of the horn. They take the horn and sell it whole, segmented or as powder on the black market.

Level 5: The consumers which, caused by the growth of the economy, consist of mostly young, wealthy Vietnamese consumers.

Sabie, therefore, is primarily host to Level 1 poachers - the men that go in and do the dirty, dangerous work. They are close to the front line and have poverty to try and leave behind (Clough, 2014; Masse et. al, 2018; Totland, 2016).

\section{South Africa Work Lures}

Having South Africa nearby is not only interesting because of poaching, but also because of other work opportunities and family matters. Many villagers in Sabie have family in South Africa that moved across the border in search of work. They dream of going to South Africa for a job, or already have gone to work in the neighboring country, or some frequent South Africa to buy and resell goods in Mozambique. For many years, locals from southern Mozambique have traveled to work in the mines of South Africa (Shangana Cultural Village, 2019), which currently accounts for 40 percent of migrant Mozambican employees in South Africa. Most in the mining industry are under legal contracts, however, some are working illegally. The South African government had deported 900,000 migrants in the years 1990-1997, of which 740,000 were from 
Mozambique (Crush \& Williams, 2001). South Africa is perceived by Mozambicans as a place to fix poverty situations, but few view it has a place to permanently live. Most legal and illegal immigrants have strong intentions on returning to Mozambique (Crush \& Williams, 2001).

\section{Importance of a Good Education}

Many developing countries, including Mozambique, have worked hard to create more access to schools and education. Since 2000, the number of schools and children attending primary school in Mozambique has more than doubled (Jones, 2017). The nation dropped the primary school fees in 2003-2004, which helped the numbers climb (Chazen, 2017). Yet the problem is having these students complete their education and a good education at that. Data from the Ministry of Education and Human Resources shows that in each grade of primary school in Mozambique, only about $80 \%$ of students pass to the next grade. Furthermore, it was shown that the quality of education in Mozambique did not match the quality of education in other developing countries. A survey completed by TPC Mozambique, part of Facilidade-ICDS (Instituto para Cidadania e Desenvolvimento Sustentavel) showed the results of testing of primary school students in different competencies, depicted in Table 1 below (Jones, 2017). Students enrolled in $3^{\text {rd }}$ and $5^{\text {th }}$ grades in rural Mozambican communities consistently scored less in subtraction and reading than the students tested in other developing countries. In fact, $3^{\text {rd }}$ and $5^{\text {th }}$ graders in Tanzania, which shares Mozambique's northern border, proved competency in subtraction in $60.8 \%$ and $82.9 \%$ of students, respectively, while the same age groups in Mozambique showed just $8.1 \%$ and $27.1 \%$ competency. Mozambican students at the same grade level as others in nearby countries are not at the same knowledge level. 
Table 1

Percent of students enrolled in $3^{\text {rd }}$ and $5^{\text {th }}$ grades that showed competent levels in each test type

\begin{tabular}{|c|c|c|c|c|c|c|c|}
\hline $\begin{array}{c}\text { Test Type } \\
\text { (Survey } \\
\text { Year) }\end{array}$ & Grade & $\begin{array}{c}\text { Pakistan } \\
\text { Rural } \\
(2013)\end{array}$ & $\begin{array}{l}\text { India } \\
\text { Rural } \\
(\mathbf{2 0 1 3})\end{array}$ & $\begin{array}{c}\text { Kenya } \\
\text { National } \\
\text { (2012) }\end{array}$ & $\begin{array}{c}\text { Tanzania } \\
\text { National } \\
(2012)\end{array}$ & $\begin{array}{c}\text { Uganda } \\
\text { National } \\
(\mathbf{2 0 1 2})\end{array}$ & $\begin{array}{c}\text { Mozambique } \\
\text { Rural } \\
(\mathbf{2 0 1 6})\end{array}$ \\
\hline \multirow{2}{*}{$\begin{array}{l}\text { Reading: } \\
\text { Story }\end{array}$} & 3 & 15.5 & 21.6 & 33.9 & 27.8 & - & 6.8 \\
\hline & 5 & 49.8 & 47.0 & 75.5 & 58.1 & - & 30.2 \\
\hline \multirow{2}{*}{$\begin{array}{l}\text { Numeracy: } \\
\text { Subtraction }\end{array}$} & 3 & 39.2 & 26.1 & 66.0 & 60.8 & 41.9 & 8.1 \\
\hline & 5 & 73.7 & 52.3 & 90.8 & 82.9 & 81.9 & 27.1 \\
\hline
\end{tabular}

It has been shown that a good education can have positive impacts on a countries' development. In a recent Organization for Economic Co-operation and Development report, providing every child with access to education and the skills required to participate in their society would boost GDP by an average of $28 \%$ per year in lowincome countries and $16 \%$ per year in high-income countries for the next 80 years (Solberg, 2015). Additionally, it has been found that education can help reduce poverty levels, create less malnutrition and hunger issues due to more educated farmers, provide equal access to education, improve water sanitation stemming from higher educated pupils developing new methods, encourage economic growth, and make their cities and communities more sustainable due to learning about alternative energy methods or other management strategies (Falae, 2018). 


\section{Conclusion}

There are a lot of challenges that adolescent boys in Mozambique face daily. While education is important for developing countries, such as Mozambique, students are not receiving a good education to achieve such goals. Furthermore, the phenomenon of boys dropping out of school more than girls is not solely happening in Mozambique.

According to the World Economic Forum's Global Gender Gap report, southern Africa countries are reporting more girls completing secondary school than boys. In fact, in Lesotho there are 157 girls for every 100 boys in secondary school, in Namibia, 127; Rwanda, 125; Swaziland, 117; and Botswana, 116 (Schwab et al., 2017). The following study will take a closer look at how the factors reviewed in this chapter have impacted the boys and the village of Sabie, Mozambique. 


\section{Chapter 3: Methodology}

This study aimed to understand the challenges young men in Sabie, Mozambique face in completing their education. This chapter focuses on how the participants were chosen, the interviews administered, and the data analyzed.

\section{Participants}

Members of three sample groups were interviewed, including current male students, males that have dropped out of school, and men in the community. These men were selected because it was thought that they would best understand the challenges that boys face in their daily life that pull them away from finishing school. Five or six participants were interviewed from each group. Prior to each interview, the participants' consent was sought to interview them and to have the interviews recorded. The interviews were mostly administered in Portuguese, but one interview was conducted in English because it was the interviewee's preference.

The interviewees that were boys currently in school were chosen based on their availability and willingness to talk, and to include a range of ages, since the researcher had access to students that ranged from 13 years old to 25 years old. The drop outs were chosen based on which boys were still around the community or that the researcher had contact with. The community members and business owners were also chosen by their availability and willingness to talk. The researcher briefed the participants about the purpose of the study and informed them that participation was voluntary and answers would be kept anonymous. The participants were given a choice to be interviewed or not. 
If the interviewee was a minor, a parent was allowed to be at the interview if they wished. The participants were requested to give verbal consent stating that they understood the purpose of the study, and that their participation was voluntary and that anonymity would be respected. The researcher aimed to interview five males in each of the three categories for a total of 15 interviews. Because of participant interest, the researcher conducted six current student interviews, five drop out interviews and six community member interviews, for a total of 17 participants. Therefore the data collected from the men was adequate to have meaningful results in the study.

\section{Data Collection}

Semi-structured interviews were used to gather information from the students and the community members, which allowed the researcher flexibility in the way she asked questions. To aid in accurately summarizing the data, the researcher recorded all of the interviews. After the interviews were transcribed and analyzed, the recordings were destroyed for confidentiality purposes.

The participants were interviewed individually in a private setting. Three interviews were conducted in person while the researcher was still in Mozambique, and the other fourteen were conducted over the phone, using voice notes to record the participants' responses. Each interview lasted about 30 minutes depending on the responses and the willingness to talk of the participant. The researcher used the questions in Figure 1 as a base to her interviews. 


\begin{tabular}{|c|c|c|c|}
\hline $\begin{array}{c}\text { QUESTION ASKED } \\
\text { improve? }\end{array}$ & $\begin{array}{c}\text { CURRENT } \\
\text { STUDENTS }\end{array}$ & DROP OUTS & $\begin{array}{c}\text { COMMUNITY } \\
\text { MEMBERS }\end{array}$ \\
\hline $\begin{array}{c}\text { What do you like about Sabie? What could } \\
\text { How long have you lived in Sabie? }\end{array}$ & $\mathrm{X}$ & $\mathrm{X}$ & $\mathrm{X}$ \\
\hline $\begin{array}{c}\text { What do you want to be when you grow } \\
\text { up? }\end{array}$ & $\mathrm{X}$ & $\mathrm{X}$ \\
\hline What do you do to earn money? & & $\mathrm{X}$ & $\mathrm{X}$ \\
\hline $\begin{array}{c}\text { What is your home life like? Where do you } \\
\text { live and whom do you live with? }\end{array}$ & $\mathrm{X}$ & $\mathrm{X}$ & $\mathrm{X}$ \\
\hline What do you do in your free time? & $\mathrm{X}$ & $\mathrm{X}$ & $\mathrm{X}$ \\
\hline $\begin{array}{c}\text { In general, how do people in Sabie earn } \\
\text { money? }\end{array}$ & $\mathrm{X}$ & $\mathrm{X}$ & $\mathrm{X}$ \\
\hline $\begin{array}{c}\text { In your opinion, why do some boys drop } \\
\text { out of school? }\end{array}$ & $\mathrm{X}$ & $\mathrm{X}$ & \\
\hline $\begin{array}{c}\text { What do the boys that drop out do instead } \\
\text { of going to school? }\end{array}$ & & $\mathrm{X}$ & $\mathrm{X}$ \\
\hline $\begin{array}{c}\text { Do you have friends that have dropped } \\
\text { out? If so, what are they doing now? }\end{array}$ & $\mathrm{X}$ & $\mathrm{X}$ & $\mathrm{X}$ \\
\hline $\begin{array}{c}\text { Why did you drop out of school? } \\
\text { What level of school have you completed? }\end{array}$ & & $\mathrm{X}$ & \\
\hline Do you think school is important? Why? & & & $\mathrm{X}$ \\
\hline Do you think about returning to school? & & & \\
\hline $\begin{array}{c}\text { What are some changes you have seen in } \\
\text { the community over the years? }\end{array}$ & & & \\
\hline
\end{tabular}

Figure 1. The main questions asked in the interviews, by participation category

\section{Data Analysis}

Coding of the interview transcripts was completed in batches according to each category of participant, including (1) current students, (2) drop outs, and (3) community members. This allowed the researcher to view the themes that emerged in each category, and find the connections between the themes within the categories at the end. After reading the transcripts several times, the researcher coded the transcripts manually and made notes in the transcripts as she saw repeated words and commonalities in ideas emerge. This is the first step of a process called open coding (Khandkar, 2009). The 
researcher then analyzed the data related to each main question and listed the common responses from each participant category. She also recorded the frequency of each response. Utilizing open coding allowed the concepts to emerge from the raw data and later be grouped into conceptual categories or themes (Khandkar, 2009). For example, when the participants were asked what they liked about Sabie, the responses shown in Figure 2 were coded and recorded.

\begin{tabular}{|c|l|l|l|l|}
\hline Theme & \multicolumn{1}{|c|}{$\begin{array}{c}\text { Current } \\
\text { Students }\end{array}$} & Drop Outs & $\begin{array}{l}\text { Community } \\
\text { Members }\end{array}$ & Total \\
\hline $\begin{array}{c}\text { Sabie } \\
\text { attractions }\end{array}$ & Respectful & Respectful & Respectful & Respectful \\
people (3) & people (1) & people (1) & people (5) \\
& Teachers (2) & Calm (1) & Calm (3) & Calm (6) \\
& Calm (2) & Environment (1) & Nature/ & Environment \\
& Friendly (2) & Home (1) & Environment & $(4)$ \\
& School (1) & Nothing (1) & $(3)$ & \\
& Family (1) & & & \\
& Agriculture (1) & & & \\
\hline
\end{tabular}

Figure 2. Responses for "Sabie attractions", along with number of participants who provided each response by each participation category

As seen in Figure 2, the researcher recognized the theme of "Sabie attractions" from the responses and listed the participants' answers below their corresponding participant category. For example, from the six community members interviewed, one liked Sabie for the respectful people it has, three liked Sabie for how calm it is, and three liked Sabie for the nature and environment, with some participants responding with more than one answer. The researcher then totaled the common answers across all three participant categories. In this way, the data can be analyzed in each individual category, as well as across the entire pool of participants. The researcher implemented this technique for each theme that she found in the data sets, using the findings to answer the research questions. 


\section{Chapter 4: Findings}

The purpose of this study was to examine the challenges that boys face in Sabie, Mozambique that cause them to drop out of school. It also examined what the boys do instead of going to school. The interview findings are discussed below.

\section{General Views of Sabie}

Almost all of the participants, except one, liked living in Sabie for some reason. Mostly it is the culture that still exists there, that attracts them to Sabie. Situated out in the country, Sabie is still very calm, mentioned by $35 \%$ of participants, with untouched natural beauty, fertile soil, and fresh air. The people are friendly and respectful, said 29\%, and the residents appreciate that. Sabie has a certain charm to it, but as any place does, has unattractive qualities as well.

Though several ideas were discussed to improve Sabie, almost $50 \%$ of the participants mentioned the road to Sabie. Currently there is really only one way to access Sabie, and that is by driving down a $40 \mathrm{~km}$, dirt, rocky road from the nearest larger village and nearest paved road that leads to the capital. In the rainy season, the condition of this road makes leaving or entering Sabie very challenging. The rocky road also quickly wears on the chapas, the local transportation vans. Participants noted that the isolation raises prices in the small stores that Sabie has and that a paved road would allow the residents access to lower priced items and encourage more business. 
"Businesses don't come here because there isn't movement. Things from here are expensive. If they were to put a paved road, the prices would also go down."

$\sim$ Drop out participant \#3

\section{Education and Dropping Out}

When asked what could improve in Sabie, 53\% of participants mentioned school in some way. Since Sabie has an incomplete secondary school, some participants mentioned how school needs to include $11^{\text {th }}$ and $12^{\text {th }}$ grade and have more university opportunities, while others mentioned students need to study more. Additionally, $71 \%$ of all participants think that school is important. The current students all have big dreams, and across all categories of participants, locals just want money. When asked what the students want to do in the future, responses such as doctor, entrepreneur, hotel manager, English teacher, and mechanical engineer were given by the boys currently still in school.

"School is the base of learning. Without school the evolution of a determined country would be very slow. All the professions depend on the teaching that are given in school."

\section{$\sim$ Current student participant \#4}

Yet, dropping out of school is a frequent occurrence. Most participants that were interviewed explained that it is most common for students to drop out after either the completion of $7^{\text {th }}$ grade or $10^{\text {th }}$ grade, while some may drop out between the two grades as well. In Table 2 below, the reasons why boys are dropping out are listed, given by each category of participants. 
Table 2

Reasons boys are dropping out, by percentages, for each participant category

\begin{tabular}{ccccc}
\hline Reason & $\begin{array}{c}\text { Current } \\
\text { Students }\end{array}$ & Drop Outs & $\begin{array}{c}\text { Community } \\
\text { Members }\end{array}$ & Total \\
\hline $\begin{array}{c}\text { Lack of } \\
\text { funds/poverty }\end{array}$ & $83 \%$ & $80 \%$ & $83 \%$ & $82 \%$ \\
\hline Poaching & $17 \%$ & $40 \%$ & $50 \%$ & $35 \%$ \\
\hline Pregnancies & $17 \%$ & $40 \%$ & $17 \%$ & $24 \%$ \\
\hline No point & $33 \%$ & $20 \%$ & $67 \%$ & $29 \%$ \\
\hline $\begin{array}{c}\text { Far away } \\
\text { school }\end{array}$ & $17 \%$ & $40 \%$ & $17 \%$ & $24 \%$ \\
\hline
\end{tabular}

In all the reasons why boys drop out, money is at the root of the issue. Out of all the participants, $82 \%$ gave the reason of poverty or not having sufficient funds as the main reason that boys drop out of school. Some students have parents that cannot afford their schooling or transportation to school, and the boys leave school to find work.

"Many boys quit studying because of lack of funds because for example a boy my age already does not have the courage to ask for enrollment money or even for worksheets. Imagine that the parents are already seniors. The biggest worry of a boy my age in this type of case is to quit studying, look for work even if it is to graze livestock. Just so he can get a job and sustain and help his parents." 
Others become involved in unplanned pregnancies, mentioned by $40 \%$ of the dropout participants, and leave school to find work to support their new family. For example, one participant said, "Now, I work. [I had to quit school] because I had a son. I have to provide for him." (Drop out participant \#2).

Still others mentioned school being far away, since the Sabie Secondary School is for the whole area, including residents that live $10 \mathrm{~km}$ away. Many students have to walk two hours, and cross the river, just to go to school, and make the same trek home afterwards. There is a school "bus" that is essentially an open back truck that students ride in the back of, however, this truck only facilitates transportation for students that live in a neighborhood called Corrumana, about $6 \mathrm{~km}$ away. Students who refer to the school being far also are referring to the fact that the Sabie Secondary School only has $8^{\text {th }}-10^{\text {th }}$ grade. Pursuing $11^{\text {th }}$ and $12^{\text {th }}$ grade requires going to Moamba, a large village $40 \mathrm{~km}$ away from Sabie, which many cannot afford.

"I would like to pursue medicine but my dad said that he wouldn't be able to have the money so I am thinking of something else."

\section{$\sim$ Current student participant \#1}

The boys that leave to find money without at least a $10^{\text {th }}$ grade certificate can still find jobs, however. One current student explained that a Chinese construction company is working locally to build new houses for locals that need to be relocated due to a dam project. The business employs many locals, but does not have an age requirement for employees. The company pays the workers 8,000 meticais a month, the equivalent of \$133 USD, and about the same amount that police officers in Mozambique earn monthly. 
This $9^{\text {th }}$ grade student explained that $70 \%$ of the resident young people and his peers worked there during the school summer break and most will not return to school since they are receiving good money. Others are not so lucky and struggle to find work, or good work, after they drop out of school, since they lack the qualifications to acquire a good job.

"The problem is that without school, the job is not anything and they pay little that neither is sufficient to sustain the family during one month and you can't even complain. Also, without school the job is not guaranteed."

\section{$\sim$ Community member participant \#1}

However, many residents still look to school in the hopes that it will help them earn money some day. One current student studying at the university level explained:

"Note that, most of us still think of school (from primary to high school) as a source of money, but at the end of the day, high school won't give you money 'cause you aren't professional with nothing, and parents end up being disappointed saying: even going to school you aren't getting money or even work."

\section{$\sim$ Current student participant \#2}

So there is disconnect between the locals' view of school, that it is important and will bring opportunities, with the reality that it really does not do so. This in turn, deters some students from completing their education and some drop out for not seeing a point in pursuing their education and viewing it as a waste of time, and turn to other ways to earn money. 
"Others [drop out] because they think that they need to have money early so they just risk poaching. School doesn't give money. It is their thinking."

\section{$\sim$ Community member participant \#2}

Poaching is a relatively new development in the Sabie area. One community member explained that poaching started in the area around year 2009 and really affects the young people. When asked why young men drop out of school, $35 \%$ of all participants mentioned poaching. This community member suggests that Sabie needs more opportunities to occupy the young people to deter them from getting involved in such an act. However, there is a lot of money that comes out of poaching, and in turn, has helped develop the small village.

"The cars that are in Sabie... were bought because of this [poaching]. The bars, shops, houses. Sabie is developing because of the rhino."

$\sim$ Drop out participant \#2

This participant also explained that the "successful" rhino poachers, meaning those that are able to kill a rhino and capture the horn, make a "ton of money" and can make much more than other common jobs, such as teachers or farmers. He explained that one kilogram sells for 400,000 meticais (\$6,666 USD), and rhino horns are not just one kilogram. However, he did not explain how much each individual receives, since many people are involved in the act of poaching one rhino horn. But he continued, "it is the adults that send the young men there. There is always a boss." Behind lack of funds/poverty, poaching was the second highest reason that boys drop out of school. 


\section{Boys Whereabouts Instead of School}

As seen in Table 3, instead of going to school, boys find themselves in different situations, all trying to earn a buck and make a living. The top two activities that boys find themselves doing instead of completing their education are poaching, reported by $35 \%$ of participants, and working in South Africa, mentioned by $29 \%$ of participants. Poaching ranked number 2 in the reasons why boys drop out; however, it is the number one activity that drop outs partake in. One participant hinted at the fact that staying in school may deter boys from entering the park by saying, "I never heard that X person already went poaching while he was a student." (Community member participant \#6). Most locals, and participants, know that poaching is illegal and very dangerous, yet it is consistently a problem and lives are lost through the experience.

"Even this year we heard that someone died there...they go because of the rhino...they poach the rhino even though there are guards that also are poaching [them, the poachers, themselves] to not kill because that's prohibited...they are only minors."

$\sim$ Drop out participant \#5

The search for money is a constant struggle. One current student explained that there is a perception that there is "no money here" and few job opportunities in Mozambique. So, boys look to South Africa in hopes of finding a job. Many have friends and/or family that already work there and go to stay with them. When asked why boys drop out, only one participant mentioned working in South Africa, yet many boys find themselves doing so instead of completing their education. 
Table 3

What boys do instead of attending school, per participant category

\begin{tabular}{ccccc}
\hline Reason & $\begin{array}{c}\text { Current } \\
\text { Students }\end{array}$ & Drop Outs & $\begin{array}{c}\text { Community } \\
\text { Members }\end{array}$ & Total \\
\hline Work in SA & $50 \%$ & $20 \%$ & $17 \%$ & $29 \%$ \\
\hline Poach & $17 \%$ & $40 \%$ & $50 \%$ & $35 \%$ \\
\hline Farms/ag & $17 \%$ & $20 \%$ & $17 \%$ & $18 \%$ \\
\hline $\begin{array}{c}\text { Private } \\
\text { Business }\end{array}$ & $67 \%$ & $20 \%$ & $0 \%$ & $29 \%$ \\
\hline
\end{tabular}

It should be noted that the private businesses referred to in Table 3 include the Chinese construction company, Bananalandia (a banana tree farm owned and run by a South African in Sabie) and PureLife (a sugar cane farm across the Incomati river but still in the greater Sabie area). There may be overlap in the responses of "farming/agriculture" and these businesses. Most residents in Sabie work in agriculture, in some way, shape or form. When asked how locals earn money, farming was mentioned in $59 \%$ of the participants' responses, next to $41 \%$ that mentioned the private businesses, followed by teaching, selling produce or goods in the market, and poaching, which each were discussed by $24 \%$ of the participants. Some locals travel to South Africa, make purchases, and re-sell the items in the Sabie market. Other jobs were listed, such as carpenters, electricians, builders, and drivers. 


\section{Summary}

Putting it simply, all the reasons boys drop out and what they find themselves doing instead of completing their education stem from financial problems. A country still recovering from a 15 -year war, and a village surviving on raising cattle, fruit and vegetable farming, and a bad road has created poverty at high levels leaving young men with few choices. 


\section{Chapter 5: Discussion and Conclusion}

The purpose of this qualitative study was to identify what challenges young men face in the village of Sabie, Mozambique that cause them to drop out of school and what they do instead of completing their education. This chapter discusses major findings of the study, including various challenges and connections to the literature on education in Africa. It also discusses what implications of the study may be valuable for use by future researchers and those working in education or social work in Mozambique or similar areas. Also included is a discussion of the limitations of the study and recommendations for future research.

\section{Discussion of Findings}

\section{Why Boys Drop Out}

After conducting interviews with local participants, including current students, drop outs and community members, it was found that the boys in Sabie drop out of school for different reasons that all generally fall under the umbrella of financial problems. Instead of continuing their education, the boys find sources of money through a variety of means.

Listed in order of severity, boys are dropping out of secondary school due to lack of funds, opportunities related to poaching, not seeing the point in school, unplanned pregnancies and school being far away. Furthermore, it was found that after dropping out, the boys find themselves poaching, working in South Africa, working in local private businesses, and working in the farms. These findings are broadly in harmony with the literature reviewed previously. 
The number one reason boys drop out is lack of funds, which is confirmed by the literature that indicated $80 \%$ of Mozambicans live on less than 2 dollars a day (Blessman, 2017). Being an area where malaria and HIV are epidemic, mixed with Mozambique being a new country still recovering from a 15-year civil war, has caused Sabie to be stricken with poverty. This is reflected in its students that struggle to complete their education and leave to find work. Households cannot afford to put their child through school locally or send their child away to finish their education, which is necessary due to Sabie's lack of a complete secondary school. Furthermore, all activities that boys do once they have dropped out involved finding money.

The number two reason that boys drop out of school is poaching. This is closely related to the number one reason, being lack of funds, since boys poach in hopes of getting rich and finding a way out of poverty. The proximity of Sabie Game Park and seeing the results of successful poachers tempts other locals, including young men that should be in school, to try their luck with obtaining the same fate.

Closely following poaching, it was found that not seeing point in a good education pulls boys from finishing school. The locals think that the idea of school is important, but also find that the image of a good education does not match their reality. Even with a good education, good job opportunities are hard to find and locals end up with a sour view on completing their education past the $7^{\text {th }}$ grade level. The perception of no value in achieving a quality education was not reflected directly in the research. However, it was shown in the literature that Mozambique lacks quality education and, further, that good education leads to greater development in an area and/or country (Jones, 2017; Solberg, 2015). 
Lastly, it was found that unplanned pregnancies can cause boys to stop their education. This is supported in the literature that explained that Mozambican education policy demands that both parents involved in the pregnancy may not attend day school (Salvi, 2008). Since Sabie Secondary School does not offer night school, the boys are left with no choice but to drop out. Typically, research has focused on the girls' side of the unplanned pregnancies, but it has been shown that the situation affects the boys, as well (Salvi, 2018).

\section{Where Boys go Instead of School}

The findings to the second research question, of where boys go instead of completing their education, mirror the reasons why boys drop out. While poaching was listed as the number two reason that boys drop out, it was found to be the number one activity that boys do instead of school.

The second most popular option for drop outs is to find work, either in South Africa or in local private businesses. Historically South Africa has been a place Mozambicans can go to find work and is still that way today. Many have friends and family that have done so already, and drop outs can easily find a starting job in the nearby country. The lure to work in local private businesses was not reflected in the literature, but surfaced in several of the interviews. These businesses are owned and run by expatriots, either South Africans, Chinese or Europeans and can employ locals, regardless of their age, and offer a competitive salary.

The last finding of where boys go instead of school is to the farms. This, too, was not reflected in the research but mirrors well the fact that Sabie is an agricultural village and would provide opportunities to work locally. The activities that drop outs do instead 
of completing their education justify that all of the reasons for dropping out of school fall under the umbrella of searching for ways to earn money.

\section{Limitations of the Study}

The primary limitation is that the study cannot be generalized nationally or regionally due to the small sample that was used. The sample consisted of male students and men that all reside in the greater Sabie region. As a result, their perceptions and ideas will only be based on what is happening within that area, and cannot be assumed to be the same in other regions of Mozambique or Africa.

\section{Implications}

The results of this study have implications for potential positive change on the individual and societal level. At the individual level, the results of this study may inform educators about which students are most vulnerable for dropping out. Much research has been reported on the reasons and frequency that girls drop out of elementary and secondary school. However, the results of this study suggest that focus needs to be given to the boys, as well, especially in this area of Mozambique. The results imply that most boys drop out due to lack of funds and home conditions. It was also shown that boys involve themselves in poaching. Encouraging and finding ways for the boys to stay in school could decrease the amount of poaching that takes place, and in turn, decrease the number of deaths related to poaching incidents.

At the societal level, the results of this study have implications for positive change for improving job opportunities, educational goals and availability in the village and across the province and/or country. For example, it was mentioned by several participants 
that if $11^{\text {th }}$ and $12^{\text {th }}$ grade had been offered locally, they might have been able to finish their education. Hence, the addition of these grades to the secondary school would give more locals access to an education. Furthermore, the road was mentioned frequently as something that needs improvement. A better road would create easier transportation to and from school for the students that live far and cannot access their school and resources. Additionally, encouraging boys to continue their education could help save the rhino population by decreasing the number of adolescents and young adults who drop out of school and become poachers. Lastly, this research implies that the more job opportunities are needed that require and respect a good education. This would motivate teens to stay in school to someday have a good paying job that reflects what they learned in their schooling. This would cause the country to be uplifted, as well, with new ideas and motivation to help develop the poverty-stricken country.

\section{Conclusion}

Utilizing semi-structured interviews, this study focused on the challenges that boys face in Sabie, Mozambique to cause them to stop their education, and investigate where they go instead of attending school. The qualitative study with participants from the community, current students and drop outs, indicated that boys mainly drop out due to their financial status and not having sufficient funds to support their academics. It was also found that when boys drop out, they find ways to make money in the nearby area, including poaching rhino horn, working in South Africa and working for local businesses and farms. Because research has been shown that quality education is important for the development of any country (Solberg, 2015), it is important that boys stay in school. By improving conditions in the area, and creating more job opportunities that respect a good 
education, boys might stay in school longer and uplift not only the village, but also the whole country. 


\section{References}

Agencia de Informacao de Mocambique. (2018). Mozambique: Nyusi urges Sabie residents to abandon poaching. Available at https://allafrica.com/stories/201805010187.html

Blessman, D. (2017). Top 10 facts about poverty in Mozambique. The Borgen Project. Available at https://borgenproject.org/about-poverty-in-mozambique/

Chazen, E. (2017). Improvements in education in Mozambique. The Borgen project. Available at https://borgenproject.org/improvements-education-in-mozambique/

Clough, L. (2014). Situational analysis of communities bordering Sabie Game Park in Mozambique. South African Wildlife College: Center for African Studies.

Club of Mozambique (2018). More than 465,000 students dropped out in primary school in 2017. Available at https://clubofmozambique.com/news/more-than-465000students-dropped-out-of-primary-school-in-2017/

Crush, J., Williams, V. (2001) Making up the numbers: Measuring "illegal immigration" to South Africa. Southern African Migration Project. Retrieved from https://www.africaportal.org/publications/making-numbers-measuring-illegalimmigration-south-africa/

Falae, V. (2018). Benefits of education in developing countries. Available at https://www.legit.ng/1138146-benefits-education-developing-countries.html

Fenio, K. G. (2014). Poaching rhino horn in South Africa and Mozambique: Community and expert views from the trenches. Available at 
https://conservationaction.co.za/wp-content/uploads/2015/02/Poaching-RhinoHorn-in-South-Africa-and-Mozambique-2014.pdf

Hsu, J. (2017). The hard truth about the rhino horn "aphrodisiac" market. Available at https://www.scientificamerican.com/article/the-hard-truth-about-the-rhino-hornaphrodisiac-market/

Jones, S. (2017). Has the quality of Mozambique's education been sacrificed at the altar of access? Available at https://www.wider.unu.edu/publication/has-qualitymozambique $\% \mathrm{E} 2 \% 80 \% 99$ s-education-been-sacrificed-altar-access

Khandkar, S. (2009). Open Coding. University of Calgary. Available at http://pages.cpsc.ucalgary.ca/ saul/wiki/uploads/CPSC681/open-coding.pdf

Lambert, T. (2018). A short history of Mozambique. Available at www.localhistories.org/Mozambique.html

Masse, F. M., Gardiner, A., Lubilo, R., \& Themba, M. N. (2017). Inclusive antipoaching? Exploring the potential and challenges of community-based antipoaching. SA Crime Quarterly, 60, 19-27.

SACMEQ: The Southern and Eastern Africa Consortium for Monitoring Educational Quality (2018). Educational Fact Sheet: Mozambique. Available at http://www.sacmeq.org/?q=sacmeq-members/mozambique/education-fact-sheet

Salvi, F. (2018). In the Making: Constructing In-School Pregnancies in Mozambique. Gender and Education, 30(40), 494-512. 
Schwab, K. S., Samans, R., Zahidi, S., Leopold, \& T. A., Ratcheva, V., Hausmann, R., \& D’Andrea Tyson, L. (2017). The global gender gap report 2017. World Economic Forum. Available at http://www3.weforum.org/docs/WEF_GGGR_2017.pdf

Shangana Cultural Village (2019). History of the Shangaan People. Available at shangan.co.za/shanganahistory.aspx

Solberg, E. (2015). Why education is the key to development. World Economic Forum. Available at https://www.weforum.org/agenda/2015/07/why-education-is-the$\underline{\text { key-to-development/ }}$

Totland, K. M. (2018). The mechanics of extinction: Rhino poaching in Mozambique Master's Thesis, University of California Berkeley Graduate School of Journalism, Berkeley, CA. Retrieved from https://escholarship.org/uc/item/2gx7d9g2 